\section{JURNAL PHRSPARINI

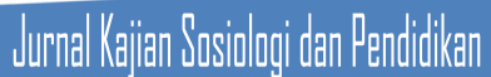

Jurnal Perspektif: Jurnal Kajian Sosiologi dan Pendidikan Vol. 3 No. 3 Tahun 2020

http://perspektif.ppj.unp.ac.id

Email: perspektif@ppj.unp.ac.id

ISSN: 2622-1748 (Online), 2684-902X (Print)

DOI: http://dx.doi.org/10.24036/perspektif.v3i3.284

\title{
Upaya Pemerintah Dalam Penanggulangan Bencana Kebakaran Hutan dan Lahan (Karhutla) di Kabupaten Sarolangun (Studi Manajemen Bencana)
}

\author{
Najmi Laila', Zikri Alhadi ${ }^{2}$ \\ 1,2 Universitas Negeri Padang \\ Email: najmilaila66@gmail.com zikrialhadi@fis.unp.ac.id
}

\begin{abstract}
Abstrak
Mayoritas masyarakat yang di daerah Sarolangun lebih dominan memiliki penghasilan dari lahan perkebunan, yang tak jarang proses pembukaan lahannya menggunakan cara yang sangat instan dan minim biaya. Tulisan ini mendeskripsikan temuan penelitian yang berupa upaya pemerintah dalam menanggulangi kebakaran hutan dan lahan (karhutla) di Kabupaten Sarolangun, peneliti menggambarkan apa saja upaya yang sudah dilakukan instansi-instansi pemerintah di Kabupaten Sarolangun pada saat bencana terjadi, kemudian untuk mengetahui program dan rencana dari masingmasing intansi pemerintah yang terkait dalam penanggulangan bencana karhutla Kabupaten Sarolangun. Hal ini dilakukan berdasarkan pelaksanaan program atau rencana yang sudah ditetapkan dari intansi-instansi terkait penanggulangan dan pencegahan bencana kebakaran hutan dan lahan (karhutla). Tujuan penelitiaan ini adalah untuk mengetahui proses berlangsungnya program ataupun rencana yang berdasarkan gugus tugas dari masing-masing instansi terkait penanggulangan bencana kebakaran hutan dan lahan. Penelitian ini menggunakan metode penelitian kualitatif yang akan menggunakan metode deskriptif, Tekhnik penelitian ini menggunakan pemilihan informan purposive sampling. Peneliti mengumpulkan data dengan cara observasi, wawancara maupun studi dokumentasi. Dapat peneliti ketahui hasil penelitian ini menjelaskan bahwasanya upaya pemerintah dalam penanggulangan bencana karhutla di Kabupaten Sarolangun untuk mencegah dan mengatasi bencana kebakaran hutan yang terjadi di Kabupaten Sarolangun berdasarkan program dan rencana yang sudah di tetapkan pemerintah Kabupaten Sarolangun.
\end{abstract}

Kata kunci: Bencana, Karhutla, Penanggulangan, Upaya

Abstract
The majority of people in the Sarolangun area have more dominant income from plantation land, which is not infrequently the process of land clearing uses a very instant and minimal cost, which is burning forests and land (forest and land) which results in environmental damage and air pollution. This paper describes the research findings in the form of government efforts in tackling forest and land fires (karhutla) in Sarolangun District, the researchers describe what efforts have been made by government agencies in Sarolangun District when disasters occur, then to find out the programs and plans of each - the government agencies involved in the management of the forest and land fire in the Sarolangun Regency. This is done based on the implementation of programs or plans that have been determined from agencies related to the prevention and prevention of forest and land fire disasters. Furthermore, the purpose and objective of this research is to know the process of the ongoing program or plan based on the task force of each agency related to disaster management of forest and land fires. This study uses qualitative research methods that will use descriptive methods, then the research technique uses the selection of purposive sampling informants. Researchers collect data by observation, interview and study documentation. Can the researchers know the results of this study explain that the government's efforts in overcoming the forest and land fire disaster in Sarolangun Regency to prevent and overcome the forest fire disaster that occurred in Sarolangun District based on programs and plans that have been set by the Sarolangun Regency Government.

Keywords: Disasters, Forest and Land, Efforts, Countermeasures. 


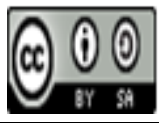

Received: July 26, 2020

\section{Pendahuluan}

Daerah Kabupaten Sarolangun adalah salah satuu daerah Kabupaten Di Provinsi Jambi yang resmi di sahkan pada tanggal 10-10-1999, yang sebelumnya Kabupaten Sarolangun dan Kabupaten Merangin bangko bergabung menjadi satu, namanya dulu adalah Kabupaten Sarko kemudian pemekaran Sarko menjadi Kabupaten Sarolangun dan Kabupaten Merangin. Peraturan Undang-undang No 54 tahun 1999 menjelaskan tentang pembentukan Kabupaten Sarolangun, selanjuntya berdasarkan putusan DPRD Provinsi Jambi Nomor 2/DPRD/99, yang ditetapkan pada tanggal 09-07-1999 tentang pembentukan Kabupaten Sarolangun yang berada di Provinsi Jambi (Sukmawati, 2017).

Daerah Kabupaten Sarolangun adalah salah satu daerah Kabupaten yang memiliki hutan dan lahan yang subur di Provinsi Jambi, sehingga tak heran sebagian besar masyarakatnya adalah petani, masyarakat Kabupaten Sarolangun memanfaatkan lahan yang subur tersebut dan mengolah lahan perkebunan seperti karet, sawit dan lain tanaman lainnya, perkebunan tersebut adalah sumber penghasilan bagi masyarakat Sarolangun. Kabupaten Sarolangun merupakan salah satu daerah lahan perkebunan yang subur di Provinsi Jambi, di Kabupaten Sarolangun terdapat banyak lahan perkebunan dan hutan yang subur, sehingga tak heran sebagian besar masyarakatnya mendapatkan penghasilan sehari-hari berdasarkan hasil perkebunan. Perkebunan yang banyak di Kabupaten Sarolangun seperti lahan perkebunan karet, dan sawit. Mayoritas masyarakat di Kabupaten Sarolangun mengolah lahan tersebut dengan cara yang instan dan biaya seminim mungkin yaitu dengan cara membakar hutan dan lahan perkebunan yang mereka miliki. Kebakaran hutan itu sendiri keadaan dimana hutan tersebut dilanda atau dilahap sijago merah yang menyebabkan terjadinya kerusakan lingkungan yang parah, dan mengakibatkan kerugian ekonomi dan kerugian lingkungan. Kebakaran hutan dan lahan sering kali diakibatkan oleh tangan manusia itu sendiri, pada zaman yang sudah modern ini masyarakat masih saja membakar hutan dan lahan untuk membuka lahan perkebunan yang baru, tanpa memikirkan dampaknya yang juga dirasakan oleh masyarakat lainnya, kebakaran hutan dan lahan yang menyebabkan terganggunya aktivitas masyarakat lainnya, seperti kegitan belajar mengajar ditiadakan untuk sementara waktu, aktivitas diluar ruangan di non aktifkan selama udara tidak sehat, dikarenakan udara tidak sehat dan jarang pandang yang sangat dekat.

Pemerintah Kabupaten Sarolangun dengan cepat menetapkan Peraturan Kabupaten Sarolangun Nomor 6 tahun 2017 pada pasal 3 tentang penanggulangan bencana, yang memiliki tujuan untuk: memberikan perlindungan dan keamanan pada masyarakat jika ada bencana yang terjadi secara terencana, serta menjamjin terselenggaranya penanggulangnan bencana secara terencan, terkoordinasi, terpadu dan menyeluruh. Untuk membangun partisipasi public maupun swasta, memajukan semangat gotong royong kedermawanan dan kesetiakawanan dalam bekerjasama, sehingga menciptakan perdamaian dalam kehidupan bermasyarakat, berbangsa maupun bernegara.

Berdasarkan hal tersebut peneliti melakukan penelitian tentang upaya pemerintah dalam penanggulangan bencana kebakaran hutan dan lahan (karhutla) di Kabupaten Sarolangun, usaha dalam pencegahan dan perlindungan bencana kebakaran ini yang sudah dilakukan oleh pemerintah kabupaten Sarolangun salah satunya adalah upaya untuk mengefektifkan perangkat hukum. Perangkat hukum yang dimaksud adalah TNI, POLRI. Penanggulangan kebakaran 
hutan dan lahan (karhutla) adalah aktivitas untuk pencegahan dan pembatasan terhadap kerusakan hutan yang diakibatkan oleh kebakaran tersebut. Kegiatan ini terdiri dari pencegahan, pemadaman serta penanganan pasca kebakaran (PP No.45 Tahun 2004). Beberapa kegiatan ini saling berkaitan dan saling mendukung. Akan tetapi, pengendalian kebakaran hutan itu sering terlihat sebagai kegiatan yang berjalan dengan baik, kemudian belum bisa memberikan hasil yang lebih baik. Penanggulangan bencana kebakaran hutan dan lahan (karhutla) adalah salah satu usaha dari pemerintah untuk mengatasi kerusakan lingkungan. Usaha yang dilakukan oleh pemerintah Kabupaten Sarolangun seperti siap siaga, mencegah terjadinya kebakaran, kemudian dilakukannya penanganan pada saat terjadi maupun sudah terjadi karhutla. Dengan ini penanggulangan bencana kebakaran hutan dan lahan (karhutla) adalah salah satu tindakan untuk melakukan persiapan sebelum terjadinya bencana.

Badan Penanggulangan Bencana Daerah (BPBD) Kabupaten Sarolangun merupakan instansi yang tugasnya adalah menangani kebencanaan. Kejadian kebakaran hutan itu sendiri merupakan bagian dari tanggung jawab BPBD Kabupaten Sarolangun (Maarif, 2014). Artikel ini bertujuan untuk meningkatkan upaya pemerintah dalam menanggulangi bencana kebakaran hutan dan lahan (karhutla), kemudian juga bertujuan untuk menyadarkan dan mengingatkan agar masyarakat menyadari bahwa tidak boleh membakar hutan dan lahan yang dapat mengakibatkan timbulnya dampak terhadap masyarakat dan bisa merugikan masyarakat lainnya, baik dari segi ekonomi, pendidikan maupun kesehatan.

\section{Metode Penelitian}

Peneliti menggunakan jenis penelitian kualitatif yang menggunakan metode deskriptif, penelitian yang peneliti lakukan berlokasi di Kabupaten Sarolangun, pemilihan informan yang peneliti gunakan adalah dengan cara menggunakan cara purposive sampling. Pengumpulan data yang peneliti lakukan menggunakan teknik observasi, wawancara dan studi dokumentasi (Maleong, 2010). Uji keabsahan data yang peneliti gunakan adalah teknik triangulasi data. Peneliti membandingkan informasi data hasil wawancara dan observasi. Peneliti melakukan teknik keabsahan data untuk mengetahui dan menjamin keabsahan data tersebut, yang diperiksa adalah data yang peneliti dapat selama berada di lapangan(Suwandi, 2008).

\section{Hasil dan pembahasan}

\section{Upaya Pemerintah dalam Penanggulangan Bencana Kebakaran Hutan dan Lahan (karhutla) di Kabupaten Sarolangun}

Hasil temuan peneliti dapat diketahui bahwasanya upaya yang dilakukan oleh pemerintah dalam menanggulangi bencana kebakaran hutan dan lahan di Kabupaten Sarolangun. Adapun indikator yang digunakan untuk Efektivitas penanggulangan bencana kebakaran hutan dan lahan di Kabupaten Sarolangun'. Dari hasil pengamatan peneliti mendapatkan data dan informasi yang berkaitan dengan Upaya Penanggulangan karhutla di Kabupaten Sarolangun. Adapun aspek rencana atau program yaitu: yang dimaksud rencana atau program disini adalah rencana dari suatu organisasi yang sudah terprogram, jika seluruh rencana dapat dilaksanakan maka rencana atau program dapat dikatakan sebagai salah satu upaya dalam penanggulangan bencana kebakaran hutan dan lahan.

BPBD Kabupaten Sarolangun membuat dan menetapkan rencana ataupun program untuk pencegahan dan penanggulangan karhutla di Kabupaten Sarolangun, akan tetapi program tersebut masih belum berjalan dengan baik, programnya berupa monitoring dan evaluasi, melakukan pemantauan penilaian terhadap operasi pemadaman karhutla, dilakukannya monitoring tersebut untuk melihat titik hotspot yang terekam pada tahun tersebut, kemudian 
adanya dampak yang diakibatkan oleh kebakaran hutan dan lahan (karhutla), selanjutnya seperti apa respon yang dilakukan dari tingkat daerah sampai nasional. Kemudian evaluasi dilakukan untuk menyesuaikan rencana dengan penerapan di lapangan dan pembelajaran yang dapat diambil dari kejadian kebakaran hutan pada tahun tersebut. Akan tetapi program ini belum berjalan sebagaimana yang diharapakan, hal ini masih terus diupayakan oleh pemerintah Kabupaten kemudian upaya-upaya yang terus dilakukan adalah sosialisasi dan juga melakukan himbauan kepada masyarakat, kemudian memberikan peringatan bahwa tidak dibenarkan membakar hutan dan lahan untuk kepentingan pribadi.

Selanjutnya BPBD Kabupaten Sarolangun juga menetapkan program yang berupa pemantauan untuk operasi pemadaman bencana kebakaran hutan dan lahan, Monitoring atau pengawasan terhadap titik hotspot yang terekam, dengan dilakukannya monitoring agar bisa mengetahui dimana saja terdapat titik hotspot, namun program ini sebenarnya belum berjalan dengan baik, dikarenakan masih ada kendala yang terdapat, pinstansi yang terkait masih kekurangan alat-alat yang akan digunakan, kemudian upaya untuk menyadarkan masyarakat dengan cara bersosialisasi mendatangi masyarakat-masyarakat dan tidak lupa kami juga memasang spanduk yang berisikan peringatan-peringatan larangan membakar hutan dan lahan.

Kemudian Dinas Lingkungan Hidup menerapkan program pencegahan dan mitigasi terhadap bencana, hal ini dianggap sebagai salah satu usaha yang dilakukan dalam rangka pencegahan dan penanganan karhutla yang bertujuan untuk menghindari dan mencegah terjadinya bencana serta mengurangi risiko yang ditimbulkan oleh bencana. Selanjutnya juga pemerintah sudah melakukan himbauan kepada masyarakat bahwasanya dilarang membakar lahan dengan sengaja, jika masih terdapat masyarakat yang membuka lahan dengan sengaja membakar maka akan diserahkan ke pihak yang berwajib untuk menindak lanjuti kasus ini, karena dampaknya juga dirasakan oleh masyarakat lainnya, dan dampaknya ini bisa membahayakan orang lain

Sejauh ini TNI/POLRI sudah memberikan sejumlah peringatan dan juga memasang spanduk di beberapa daerah, tidak lupa juga mencantumkan Peraturan daerah Kabupaten Sarolangun No 32 tahun 2009, tentang Lingkungan Hidup. Kemudian ancaman penjara 10 Tahun dan Denda 15 Milyar. Jika ada masyarakat yang terdapat membakar hutan dan lahan untuk kepentingan pribadi, maka akan segera ditindak lebih lanjuti agar segera diproses, dan ini adalah salah satu efek jera bagi masyarakat yang tidak bisa mengikuti aturan yang sudah ditetapkan.

Berdasarkan ungkapan dari Dinas Pemadam dan Penyelamatan Kabupaten Sarolangun, mereka berusaha menerapkan program tanggap darurat yang merupakan tahap tindakan atau arahan pertolongan kepada masyarakat, kemudian upaya yang akan dilakukan selanjutnya dalam Menanggulangi Bencana Kebakaran hutan dan lahan (karhutla) di Kabupaten Sarolangun, hal yang dilakukan pemerintah yaitu menyadarkan masyarakat bahwasanya tidak dibenarkan membakar hutan dan lahan demi kepentingan pribadi, dan juga menjelaskan bahwa banyak sekali dampaknya jika membuka lahan dengan cara membakar, dampak dari kebakaran lahan ini juga dirasakan oleh seluruh masyarakat sekitar Kabupaten Sarolangun.

Sejauh ini masyarakat juga mengatakan upaya yang sudah dilakukan pemerintah dalam menanggulangi bencana kebakaran hutan dan lahan (karhutla) di Kabupaten Sarolangun yaitu pemerintah terus saja melakukan sosialisasi kepada masyarakat awam yang tidak memikirkan dampak yang terjadi akibat kebakaran hutan dan lahan ini, membuka lahan dengan cara yang instan dan hemat biaya, tidak memerlukan banyak waktu, tetapi tetap saja cara ini tidak di benarkan oleh pemerintah dan sangat dilarang. Selain itu pemerintah juga sudah memasang spanduk tidak dibenarkan masyarakat membuka hutan dan lahan dengan cara membakar, 
Rica Sandra, Erianjoni Erianjoni Konstruksi Masyarakat terhadap Suami yang Tidak Bekerja dalam Keluarga di Nagari Paninggahan Kecamatan Junjung Sirih Kabupaten Solok

spanduk tersebut berisi peraturan dan undang-undang tidak boleh membakar hutan, dan juga pemerintah mencantumkan sanksi beserta denda jika masih ada yang melanggar peraturan tersebut.

Program yang sudah terapkan oleh Daops Manggala Agni Sumatera XIII Kabupaten Sarolangun adalah berupa mencegah dan menanggulangi kebakaran hutan dan lahan telah dilakukan, berupa early worning system atau peringatan, pemantauan hotspot atau deteksi dini, kemudian patroli, sosialisasi atau kampanye kepada masyarakat, koordinasi dan peningkatan sumberdaya manusia serta memberikan teguran-teguran kepada masyarakat bahwasanya tidak di perbolehkan membuka hutan dan lahan dengan cara membakar, jika terdapat hal demikian kami akan melaporkannya ke pihak yang berwajib.

\section{Pembahasan}

Dari beberapa penjelasan diatas dapat disimpulkan bahwasanya instansi-instansi pemerintah di Kabupaten Sarolangun mempunyai rencana dan program masing-masing serta masyarakat yang ikut terlibat dalam upaya pemerintah dalam mengatasi bencana yang terjadi di Kabupaten Sarolangun, dengan berbagai usaha yang telah dilakukan pemerintah salah satunya sosialisasi untuk menyadarkan masyarakat awam yang hanya memikirkan kepentingan dan kepuasan pribadi dan tidak memikirkan dampak dari membuka lahan dengan cara membakar serta pemerintah juga menjelaskan denda dan sanksi untuk orang yang berlaku demikian. Usaha yang telah dilakukan pemerintah dalam mencegah dan menanggulangi kebakaran hutan dan lahan berupa menerapkan pengendalian kebakaran hutan dan lahan yang terbagi pada dua situasi. Pada saat keadaan normal tidak adanya kebakaran belum ditetapkan pimpinan daerah dengan status siaga darurat, kebakaran yang akan ditangani oleh lembaga dan instansi di wilayah kerjanya masing-masing. Jika keadaan menjadi darurat maka instansiinstansi pemerintah yang terkait akan bergabung untuk mencegah, menanggulangi dan memadamkan kebakaran. Keterlibatan instansi-instansi terkait bencana kebakaran tersebut berada dalam satu wadah yaitu Satuan Tugas mencegah, menanggulangi dan penanganan pasca kebakaran hutan dan lahan yang dibentuk oleh pimpinan daerah Kabupaten Sarolangun.

Penelitian-penelitian yang dilakukan sebelumnya yang berkaitan dengan penelitian yang dilakukan oleh peneliti antara lain yaitu: Penelitian yang dilakukan oleh Sunanto (Sunanto, 2008) tentang Peran Masyarakat dalam Pencegahan dan Penanggulangan Kebakaran Lahan, penelitian yang dilakukan oleh Susanto ini berfokus pada peran kelompok masyarakat yang peduli terhadap pencegahan dan penanggulangan kebakaran lahan, serta berfokus pada mengapa sampai saat ini kejadian kebakaran di Kecamatan Ransau Jaya masih terjadi. penelitian yang dilakukan oleh Susanto ini masih belum berjalan secara optimal, dikarenakan kelompok masyarakat yang peduli api ini masih cenderung bersifat formalitas, kemudian hanya memenuhi intruksi saja, sehingganya masih belum melaksanakan tugas dan fungsi pokoknya dengan baik. Kemudian penelitian yang dilakukan oleh Andriyas Syaputra (Syaputra, 2014), yang membahas tentang Analisis Peran Pemerintah Dalam Penanggulangan Kerusakan Hutan dan Lahan di Provinsi Riau, yang studi kasusnya di Kabupaten Rokan Hulu, penelitian yang dilakukan oleh Andriyas ini berfokus pada peran pemerintah khususnya pemerintah rokan hulu dalam penanggulangan kerusakan hutan dan lahan kemudian faktor yang menyebabkan kerusakan hutan tersebut, penelitian yang dilakukan Andriyas ini mengatakan peran pemerintah terhadap penanggulangan kebakaran hutan dan lahan masih belum berjalan dengan baik. Kedua penelitian tersebut saling berkaitan dengan penelitian ini karena sama-sama membahas penanggulangan kebakaran hutan dan lahan, akan tetapi penelitian yang dilakukan oleh Susanto membahas tentang Peran Masyarakat dalam Pencegahan dan Penanggulangan Kebakaran Lahan, sedangkan penelitian yang dilakukan oleh Andriyas Syaputra yang 
membahas tentang Analisis Peran Pemerintah Dalam Penanggulangan Kerusakan Hutan dan Lahan, Peneliti menggunakan kedua penelitian tersebut sebagai perbandingan dan bahan analisa saja.

\section{Kesimpulan}

Dapat disimpulkan bahwasanya membuat dan menetapkan aspek rencana atau program adalah upaya yang sudah dilakukan pemerintah untuk menanggulangi bencana kebakaran hutan dan lahan (karhutla) adalah berupa pemerintah sudah melakukan sosialisasi kemudian pemerintah juga sudah memasang spanduk-spanduk yang berisikan peraturan perundangundangan serta sanksi jika masih ada masyarakat yang melanggar hal tersebut, pemerintah sudah menetapkan dan menegaskan peraturan-peraturan larangan membakar lahan agar tidak ada lagi masyarakat yang masih bertekat membakar lahan, karena jika hal ini masih saja dilakukan maka akan menimbulkan banyak sekali dampak yang disebabkan oleh karhutla, seperti berdampak pada kesehatan masyarakat, ekonomi, maupun pendidikan. Penanggulangan karhutla yang dilakukan oleh pemerintah dalam proses mengatasi dan mengendalikan kerusakan hutan yang diakibatkan oleh kebakaran yang terjadi secara sengaja. Aktivitas tersebut meliputi proses mencegah, memadamkan serta menangani pasca kebakaran. Aktivitas ini saling berkaitan dan mendukung kegiatan lainnya yang berhubungan dengan proses penanggulangan karhutla. Akan tetapi, aktivitas pengendalian dan pencegahan kebakaran hutan itu sendiri sering dilihat sebagai kegiatan yang belum dilaksanakan dengan baik dan benar, sehingga belum dapat memberikan hasil yang lebih baik. Sejauh ini pemerintah sudah berusaha untuk mengatasi dan mengendalikan karhutla di Kabupaten Sarolangun, pemerintah juga sudah melakukan kerjasama dengan instansi-instansi yang terkait, meskipun sebenarnya tidaklah mudah untuk menyatukan instansi-instansi tersebut. Kemudian pemerintah Kabupaten sarolangun sudah menetapkan ketentuan Peraturan Undang-undang No 32 Tahun 2009 Tentang Lingkungan Hidup, Ancaman Penjara 10 Tahun dan Denda 10 Milyar. Kemudian larangan merusak lingkungan yang termasuk membakar hutan, didalam peraturan tersebut juga diteapkan sanksi yang berlaku jika masih ada yang melanggarnya, beberapa tanggapan pemerintah dan jajarannya serta masyarakat di sekitar lokasi kejadian terbakarnya hutan dan lahan, mengenai penanggulangan bencana karhutla di Kabupaten Sarolangun, pemerintah masih terus berusaha dalam menghentikan karhutla ini, salah satu upaya dalam menanggapinnya adalah dengan cara bekerjasama membuat tim dalam pembagian tugas masing masing serta menyadarkan masyarakat bahwa dilarang keras membuka hutan dan lahan dengan cara membakar. Hal tersebut diharapkan bisa membantu mengatasi penanggulangan karhutla di Kabupaten Sarolangun.

\section{Daftar Pustaka}

Maarif, S. (2014). Rencana Nasional Penanggulangan Bencana 2015-2019. Jakarta: BNPB. Maleong, L. J. (2010). Metode Penelitian Kualitatif. Jakarta: PT Remaja Rosdakarya. Muasaroh. (2010). Aspek-aspek Efektivitas. Jakarta: Mega Ilmu.

Sukmawati, N. (2017). Efektivitas Implementasi Kebijakan Peraturan Daerah Nomor 23 Tahun 2007 Tentang Penertiban Dan Pemeliharaan Ternak Di Kabupaten Sarolangun. Skripsi. Universitas Negeri Padang.

Sunanto, S. (2008). Peran Serta Masyarakat dalam Pencegahan dan Penanggulangan Kebakaran Lahan. Tesis. Universitas Diponegoro.

Suwandi, B. dan. (2008). Memahami penelitian kualitatif. Jakarta: Rieneka Cipta. 
Syaputra, A. (2014). Analisis Peran Pemerintah dalam Penanggulangan kerusakan Hutan dan Lahan di Provinsi Riau. Skripsi. Universitas Negeri Padang.

Peraturan Daerah Kabupaten Sarolangun Nomor 6 Tahun 2017 Tentang Penanggulangan Bencana.

Peraturan Pemerintah Republik Indonesia Nomor 45 Tahun 2004 Tentang Perlindungan Hutan. Undang-Undang Republik Indonesia Nomor 32 Tahun 2009 Tentang Perlindungan dan Pengelolaan Lingkungan Hidup. 
Najmi Laila, Zikri Alhadi

Upaya Pemerintah Dalam Penanggulangan Bencana Kebakaran Hutan dan Lahan di Kabupaten Sarolangun 